\title{
ONLINE LEARNING PERFORMANCE: THE STUDENTS' PERSPECTIVE
}

\author{
Jasmina Starc ${ }^{1}$
}

DOI: https://doi.org/10.31410/LIMEN.S.P.2020.93

\begin{abstract}
The paper's contribution is to present the opinion of students of the University of Novo mesto about the implementation of online studies. The quantitative research method and a structured questionnaire were used for collecting research data. The research sample comprised 387 students. The results showed that only $36 \%$ of students were trained to use various forms of online study before conducting online studies. Among the advantages of online learning, they recognized the fact that they did not waste time driving to faculty/university (4.2), which resulted in lower costs (4.1), making it easier to coordinate study and family obligations (4.0), had the possibility of time flexibility (4.0) and "learned" self-discipline (4.0). Among the shortcomings was the lack of personal contact with teachers (3.8), the lack of personal contact with study colleagues (3.7), being left with one's ingenuity (3.3) and one's own self-initiative and self-discipline (3.1).
\end{abstract}

Keywords: Full and part-time students, University of Novo mesto, Online learning.

\section{INTRODUCTION}

$\mathrm{S}$ lovenia is not the most advanced in the process of digital transformation. From the point of view of providing educational opportunities in accordance with the needs of the digital society, it is particularly worrying that we are lagging behind in the development of human capital and the use of Internet services (Bregar, Zagmajster, Radovan, 2020, pp. 1-2).

The educational programs offered by educational organizations and other education providers in our country today have not yet been designed in such a way as to enable learners to acquire the skills needed in an open, rapidly changing and digitalized society (Bregar et al., 2020, p. 2). Because of the COVID-19 epidemic, the use of information and communication technology (ICT) is a daily practice, and the question is how many opportunities the ICT offers we actually take advantage of. In learning, students largely use multimedia online learning resources, through which they have the opportunity to completely personalize learning and adjust it according to their previous knowledge, experience and interest (Kiswarday, 2018, p. 71). The introduction of ICT encourages teachers to improve the way they learn through interactive and dynamic resources that enable them to use ICT and provide more motivation and a richer learning experience for students (Brečko and Vehovar, 2008).

Online education is not homogeneous and we find different approaches in it. Some are consistent with advances in technology, while others are based on different didactic paradigms (Krašna, 2015, p. 25). Awareness that technology alone is not more effective and that the amount of multimedia does not necessarily contribute to better knowledge has raised the importance of pedagogy and didactics. They were given the additional task of selecting or

1 University of Novo Mesto Faculty of Business and Management Sciences, Na Loko 2, 8000 Novo mesto, Slovenia 
developing the pedagogical work that will derive the most benefit from the technological given. This has influenced pedagogical shifts and shifts in didactics to look for methods of effective education at all levels of formal education in new, technologically more developed circumstances. Pedagogy and didactics can guide the development of learning technology (Rebolj, 2008, p. 28). This is very important, as Daymont and Blau (2008) argue that online study does not have much success compared to classical lectures, and also requires a lot of selfdiscipline and organization of time and study from students. Therefore, Bitenc, Werber and Urh (2020, p. 12) also confirm this finding based on their own research and suggest that teachers constantly encourage students to work independently, regularly and continuously. At the same time, we must not forget the didactic principles that must be followed for the good implementation of online studies (Jevnikar, 2015, p. 249; Volk, 2018, pp. 41-42): students' learning activity, unity of visual and conceptual, structure and systematic teaching, rationality and economy of teaching, problematic teaching and learning differentiation and individualization. Among the advantages of online study, Bregar et al. (2020) include the possibility of an education that would not be feasible in traditional circumstances (e.g. the COVID-19 epidemic), cheaper organization and cheaper and faster delivery of education, better use of available ICT, improved information literacy of lecturers and students, the possibility of fast and usually simple adapting educational content to students 'needs, greater flexibility in time, place, pace and content of education, greater interactivity and faster access to knowledge from various sources, the possibility of adapting learning approaches to students' needs, transparency and documentation of the pedagogical process and its consistent implementation, the introduction of modern pedagogical models and innovation of the pedagogical process, etc.

Since the Government of the Republic of Slovenia adopted a decree which temporarily banns the gathering of people in educational institutions, universities and independent higher education institutions in the annual semester 2019/2020 to contain and control the COVID-19 epidemic, we at the University of Novo mesto, have carried out the entire pedagogical process online to the extent enabled by the appropriate communication technology since March 2020 .

\section{METHODOLOGY}

\subsection{Purpose and goals of the research}

The purpose of the research is to examine the opinions of students of the University of Novo mesto about the implementation of online studies.

The goals of the research are:

- to analyze the satisfaction of students with the implementation of various forms of studying during the epidemic and the execution of the pedagogical process online,

- to analyze the level of satisfaction of students, with cooperation with teachers during the epidemic and the course of the online pedagogical process,

- identify the benefits of online studies perceived by students,

- identify shortcomings of online study perceived by students.

\subsection{Research questions}

Depending on the purpose and goals of the research, we asked the following research questions:

1. How satisfied were the students with the implementation of various forms during the epidemic and the course of the pedagogical process at a distance? 
2. How satisfied were the students with the cooperation with teachers during the epidemic and the course of the online pedagogical process?

3. What benefits of online learning did students perceive?

4. What shortcomings of the online study did students perceive?

\subsection{Research methods and technique}

The quantitative research method and a structured questionnaire with different sets of questions were used for collecting research data.

We have used the quantitative method. A structured questionnaire with different sets of questions was used to collect the data. We compiled a questionnaire by relying on the theoretical starting points of various authors (Bregar et al., 2020; Istenič Starčič and Lebeničnik, 2020; Tratnik, 2016; Puhek and Amič, 2016). The online survey was used as the method of data collection. Absolute and relative frequencies were calculated, and average ratings for the scales. Students assessed satisfaction with the implementation of various forms of study, satisfaction with the cooperation with teachers during the epidemic and the distance pedagogical process, and the advantages and disadvantages of online study according to the scale model.

\subsection{Sample}

The basic population of the sample is represented by 677 full-time and part-time students studying at the University of Novo mesto. The study involved 387 students of the summer semester in the academic year 2019/2020. $43 \%$ were full-time students and 57\% were parttime students. At the time of the survey, $86 \%$ of them were studying at the $1^{\text {st }}$ cycle, $10 \%$ at the $2^{\text {nd }}$ cycle and $4 \%$ at the $3^{\text {rd }}$ cycle of the study program. $12 \%$ of students studying at the Faculty of Economics and Informatics and the Faculty of Business and Management Sciences, 72\% at the Faculty of Health Sciences and $16 \%$ at the Faculty of Mechanical Engineering. Among them, $79 \%$ were female students and $21 \%$ male students. At the start of the online study, $36 \%$ were trained to use various forms of online study, 34\% were partially trained and $30 \%$ were not trained. $61 \%$ of the surveyed students thought they were sufficiently self-disciplined for online studies, $25 \%$ thought they were partially self-disciplined and 14\% thought they were not self-disciplined enough for online studies.

\section{RESULTS AND DISCUSSION}

This part of the analysis of the study is the basic descriptive statistical analysis, for which the results are presented below. The next question focused on the respondents' opinions on the satisfaction with the implementation of various forms of online learning during the epidemic and the course of the pedagogical process online. The respondents assessed a set of statements on a scale of 1 to 5, with 1 meaning "I am very satisfied" and 5 "I am very dissatisfied". The results are shown in Table 1.

Table 1 shows that the respondents were most satisfied with video conferencing (3.9) and electronic communication (3.8). The lowest level of satisfaction was expressed for online materials (3.4) and the online classroom Moodle (3.2). 
Table 1. Satisfaction with the implementation of various forms of study during the epidemic and the execution of the pedagogical process online

\begin{tabular}{|ll|c|c|c|c|}
\hline Form of study & M & SD & n \\
\hline E - mail & & 3,8 & 1,0 & 387 \\
\hline online classroom Moodle & & 3,2 & 1,2 & 387 \\
\hline $\begin{array}{l}\text { video conferencing (MS Teams, Zoom, Skype, Webex, } \\
\text { GoToMeeting) }\end{array}$ & 3,9 & 1,0 & 387 \\
\hline \begin{tabular}{l} 
online materials \\
\hline
\end{tabular} & & 3,4 & 1,1 & 387 \\
\hline
\end{tabular}

Note: $\mathrm{M}$ - mean, $\mathrm{SD}$ - standard deviation, $\mathrm{n}$ - number of answers

Source: Own calculation

The next set of statements refers to the activities of teachers during the online study and to what extent they encouraged and motivated students during their online studies. The respondents assessed the statements on a scale of 1 to 5, with 1 meaning "I completely disagree" and 5 "I completely agree".

Table 2. Activities of teachers during online study

\begin{tabular}{|l|c|c|c|}
\hline Statement & M & SD & n \\
\hline $\begin{array}{l}\text { The lecturers encouraged me to use an online learning environment } \\
\text { for learning. }\end{array}$ & 3,6 & 1,0 & 387 \\
\hline The lecturers provide appropriate support. & 3,5 & 1,0 & 387 \\
\hline The lecturers gave me clear written instructions for individual work. & 3,6 & 1,0 & 387 \\
\hline The lecturers gave me clear oral instructions for individual work. & 3,6 & 0,9 & 387 \\
\hline The lecturers motivate me to continue individual work. & 3,5 & 1,0 & 387 \\
\hline The lecturers motivated me to keep learning. & 3,5 & 1,0 & 387 \\
\hline The lecturers gave feedback on my individual work regularly. & 3,4 & 1,1 & 387 \\
\hline The lecturers checked my attendance at lectures and tutorials. & 4,1 & 0,9 & 387 \\
\hline $\begin{array}{l}\text { The lecturers contacted me by email if I was absent from lectures and } \\
\text { tutorials. }\end{array}$ & 2,8 & 1,3 & 387 \\
\hline $\begin{array}{l}\text { The lecturers required the same level of knowledge from me as if the } \\
\text { lectures/ tutorials were conducted by direct communication (in the } \\
\text { lecture room). }\end{array}$ & 3,8 & 1,1 & 387 \\
\hline
\end{tabular}

Note: $\mathrm{M}$ - mean, SD - standard deviation, $\mathrm{n}$ - number of answers

Source: Own calculation

Lecturers mostly checked the attendance of students in lectures and tutorials (4.1), required the same level of knowledge as if the pedagogical process was carried out through direct communication (3.8), encouraged students to use different online learning environments (3.6), gave clear written and oral instructions for individual work (3.6), sent feedback less regularly (3.4), provided appropriate support (3.5) a little less intensively, motivated students to continuous learning (3.5) and motivated them to continuous individual work (3.5). However, they do not agree with the statement that higher education teachers contacted students if they were absent from lectures and tutorials (2.8).

The next set of factors refers to the advantages of online learning. The respondents assessed the factors of online learning on a scale of 1 to 5, with 1 meaning "not important at all" and 5 "very important".

Table 3 shows that the respondents thought the following factors were the most important in terms of advantages of online learning: not wasting time driving to faculty/university (4.2), 
time flexibility (4.0), lower costs (4.1), requires a lot of self-discipline (4.0), easier fulfillment of studies and family obligations (3.9), more free time (3.8) and easier fulfillment of official obligations and studies/work through student service and studies. However, the respondents prefer classical forms of knowledge transfer (3.8). The following factors were rated of medium importance as an advantage of online learning: study at home (3.7), greater independence when learning (3.6), online learning is equivalent to classical education (3.3), and more creative learning (3.2). The lowest level of agreement was achieved by the statement that online learning is more interesting than classical learning (2.9).

Table 3. Advantages of online learning

\begin{tabular}{|l|c|c|c|}
\hline Factor & M & SD & n \\
\hline time flexibility & 4,0 & 1,0 & 387 \\
\hline study at home & 3,7 & 1,2 & 387 \\
\hline there is no waste of time driving to faculty/university & 4,2 & 1,2 & 387 \\
\hline lower costs & 4,1 & 1,2 & 387 \\
\hline more free time & 3,8 & 1,2 & 387 \\
\hline $\begin{array}{l}\text { easier fulfillment of official obligations and studies/work through } \\
\text { student service and studies }\end{array}$ & 3,7 & 1,3 & 387 \\
\hline easier fulfillment of studies and family obligations & 3,9 & 1,2 & 387 \\
\hline greater independence in study & 3,6 & 1,2 & 387 \\
\hline customized learning & 3,7 & 1,2 & 387 \\
\hline more creative study & 3,2 & 1,3 & 387 \\
\hline more interesting than classical study & 2,9 & 1,4 & 387 \\
\hline requires a lot of self-discipline & 4,0 & 1,1 & 387 \\
\hline online learning is equivalent to classical education & 3,3 & 1,4 & 387 \\
\hline I prefer classical forms of knowledge transfer & 3,8 & 1,2 & 387 \\
\hline
\end{tabular}

Note: $\mathrm{M}$ - mean, $\mathrm{SD}$ - standard deviation, $\mathrm{n}$ - number of answers

Source: Own calculation

The next set of factors refers to the shortcomings of online learning. The respondents assessed the factors of shortcomings of online learning on a scale of 1 to 5, with 1 meaning "not a shortcoming" and 5 "a major shortcoming".

Table 4. Shortcomings of online learning

\begin{tabular}{|l|c|c|c|}
\hline Factor & M & SD & n \\
\hline lack of personal contact with other students & 3,7 & 1,2 & 387 \\
\hline lack of personal contact with teachers & 3,8 & 1,1 & 387 \\
\hline being left with one's own ingenuity & 3,3 & 1,2 & 387 \\
\hline being left with one's own self-initiative & 3,1 & 1,2 & 387 \\
\hline being left with one's own self-discipline & 3,1 & 1,2 & 387 \\
\hline poor ICT knowledge of teachers & 3,0 & 1,1 & 387 \\
\hline poor ICT knowledge of other students & 2,8 & 1,1 & 387 \\
\hline My own poor ICT knowledge & 2,6 & 1,2 & 387 \\
\hline poorly prepared e-materials & 3,0 & 1,2 & 387 \\
\hline low teacher responsiveness & 2,9 & 1,2 & 387 \\
\hline
\end{tabular}

Source: Own calculation

Table 4 shows that major shortcomings of online learning are: lack of personal contact with teachers (3.8), lack of personal contact with other students (3.7) and being left with one's own 
ingenuity (3.3). The respondents saw as less important shortcomings in the following factors: being left with one's own self-initiative (3.1), being left with one's own self-discipline (3.1), poor ICT knowledge of teachers (3.0), poorly prepared e-materials (3.0), low teacher responsiveness (2.9), poor ICT knowledge of other students (2.8) and my own poor ICT knowledge (2.6).

\section{CONCLUSION}

The results of the survey, which consisted of a sample of 387 full-time and part-time students studying at the faculties of the University of Novo mesto, showed that lecturers performed their lecturers and tutorials online relatively well. The faculties had switched from the classic form of pedagogical process to online learning practically "overnight". Since there was no time to prepare relevant materials for online implementation, and there was no prior preparation and training on the use of ICT for neither teachers nor students, we believe that teachers and students did a good job.

Certainly, the results of the research show that everyone, teachers and students, must prepare properly for the online form of learning in advance and be aware, that this form has its advantages and disadvantages. We could observe the lack of knowledge on ICT practices for both lecturers and students. This should be the motivating factor for them to study different forms of online learning. This will give the lecturers to be more satisfied with the organization and implementation of online learning that will, according to the current epidemiological situation, last quite some time. The students, on the other hand, will be able to use all available tools to gain new knowledge, information and study materials provided by the lecturers.

It would be interesting to repeat the survey after the end of the winter semester in the academic year 2020/2021 and, by comparing the results, determine whether there are differences of opinion about online learning, especially in the context of advantages and disadvantages of this form of study. The key to achieving student satisfaction and success is the continuous overall support of the faculty at the pedagogical, organizational, technical and administrative level of operation.

\section{REFERENCES}

Bitenc, I., Werber, B., \& Urh, M. (2020). Kombinirano učenje - izkušnje in rešitve. Uporabna informatika, 28 (1), str. 3-13.

Brečko, B. N., \& Vehovar, V. (2008). Informacijsko-komunikacijska tehnologija pri poučevanju in učenju v slovenskih šolah. Ljubljana: Pedagoški inštitut.

Bregar, L., Zagmajster, M., \& Radovan, M. (2020). E-izobraževanje za digitalno družbo. Ljubljana: Andragoški center Slovenije.

Dajmond, T., \& Blau, G. (2008). Student performance in on-line and traditional sections of an undergraduate management course. Journal of Behavioral and Applied Management, 9

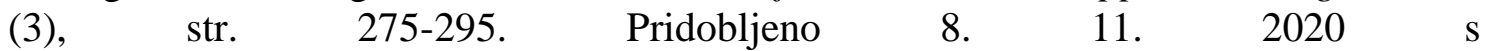
https://www.researchgate.net/publication/242676476_Student_Performance_in_Online _and_Traditional_Sections_of_an_Undergraduate_Management_Course

Istenič Starčič, A., \& Lebeničnik, M. (2020). Investigation of university students' perception of their educators as role models and designers of digitalized curricula. Human technology, 16 (1), str. 55-91. 
Jevnikar, U. (2015). E-izobraževanje. In Boštjančič, E. (ur.), Potočnik, A. (ur.), \& Šavrič, K. (ur.) Organizacijska psihologija danes in jutri. Ljubljana: Znanstvena založba Filozofske fakultete Univerze v Ljubljani, str. 243-259.

Kiswarday, V. (2018). Uporaba IKT v procesu visokošolskega učenja za bolj doživeto razumevanje pomena prilagojenega učnega okolja in izboljšanje dostopnosti učinkovitega učenja otrokom s posebnimi potrebami. In Čotar Konrad S. (ur.), \& Štemberger, T. (ur.) Strokovne podlage za didaktično uporabo informacijskokomunikacijske tehnologije in priporočila za opremljenost šol. Koper: Založba Univerze na Primorskem, str. 71-76.

Krašna, M. (2015). Izobraževanje v digitalnem svetu. Maribor: Mednarodna založba Oddelka za slovanske jezike in književnosti, Filozofska fakulteta.

Puhek, M., \& Amič, I. (2016). Pomen celostne podpore študentom pri v celoti spletno podprtem študiju na daljavo. In Aškerc. K. (ur.) et al. Izboljševanje procesov učenja in poučevanja $v$ visokošolskem izobraževanju: zbornik konference = Improving teaching and learning processes in higher education: conference proceedings. Ljubljana: Center RS za mobilnost in evropske programe izobraževanja in usposabljanja, str. 134-139.

Rebolj, V. (2008). E-izobraževanje skozi očala pedagogike in didaktike. Radovljica: Didakta.

Tratnik, A. (2016). E-izobraževanje z vidika študenta. In Aškerc. K. (ur.) et al. Izboljševanje kakovosti poučevanja in učenja $v$ visokošolskem izobraževanju: od teorije $k$ praksi, od prakse $k$ teoriji = Improving the quality of teaching and learning in higher education: from theory to practice, from practice to theory. Ljubljana: Center RS za mobilnost in evropske programe izobraževanja in usposabljanja, str. 173-181.

Volk, M. (2018). Interaktivna tabla. In Čotar Konrad, S. (ur.), \& Štemberger, T. (ur.) Strokovne podlage za didaktično uporabo informacijsko-komunikacijske tehnologije in priporočila za opremljenost šol. Koper: Založba Univerze na Primorskem, str. 39-42. 